\title{
ENVIRONMENTAL TRIALS OF A MODEL POPULATION OF PHASEOLUS VULGARIS L. IN CONTRAST CLIMATES
}

\author{
Bezugla O.M., Kobyzeva L.N., Vus N.M., Solonechnyi P.M.
}

Plant Production Institute nd a V.Ya. Yuriev of NAAS, Ukraine

The study purpose was to evaluate the potentials of bean genotypes in contrast climates, to identify the most informative environments for assessing the adaptability of genotypes, to select promising starting material for specific areas where this crop is supposed to be bred. To accomplish this purpose, environmental trials were conducted on a collection of bean (Phaseolus vulgaris L.) accessions in four sites located in different climatic zones of Ukraine: the eastern Forest-Steppe - Kharkiv region; southern Forest-Steppe - Poltava region; Woodlands - Chernivtsi region; southern Steppe - Odesa region. Genotypes and environments were evaluated using the GGE biplot method, which allowed us to graphically visualize the environmental trial data. To develop cultivars for different zones of Ukraine, we recommend selecting parents, taking into account the weather conditions: drought- and highly heat-tolerant genotypes (Holberg) for the south of Ukraine; intensive genotypes (Pervomaicka, Mistseva Bomba 5) for Woodlands; genotypes with stable yields and high drought tolerance (Holberg, Nadiia, UD0300104) for ForestSteppe. The GGE biplot analysis distinguished the most informative environments allowing full assessments of the adaptability of genotypes - the Forest-Steppe of Ukraine (Kharkiv region and Poltava region). The genotypes with stable yields of seeds were identified: Holberg, Otrada, UD0300104, Bogema, UD0300152, N 201-15 and Synelnykivska 8. Of these accessions, Holberg, Otrada, UD0300104 and Synelnykivska 8 gave high yields, and Holberg and UD0300104 approached the "ideal" genotype. The southern subzone of the Steppe is the most informative for identification of drought- and heat-tolerant bean accessions; the Woodlands - for selection of genotypes with high potential yields.

\section{Key words: bean, genotype, environment, GGE biplot}

Introduction. Evaluation of the "genotype $\times$ environment" interaction is very important for selection of starting material used in breeding [1,2]. It is well known that one of the parents in hybridization should be a genotype that is well-adapted to local climatic conditions [3]. Valuable features of a collection accession (genotype) will be negated by unfavorable environmental conditions, if they are not taken into account [4]. Most modern bean cultivars having sufficiently high potential yields are characterized by low homeostaticity and adaptability to unfavourable environmental factors [5]. Therefore, when developing new cultivars, one should use genotypes that are adapted to the conditions of a particular zone. In order to get an idea of the responses of bean accessions to an environment, we formed a model population, which included genotypes with various characteristics according to the multi-year data from the National Center for Plant Genetic Resources of Ukraine (NCPGRU) [6]. The effects of abiotic factors on the yields of bean accessions were studied [7], and, as a result, a trait collection of Phaseolus vulgaris L. was compiled [8]. This collection became the basis of the model population [9], in which each genotype is original and has an extensive range of adaptive features allowing it to adapt to the growing conditions.

The purpose of our study was evaluate the potentials of bean genotypes in contrast environments, to identify the most informative environments for assessing the adaptability of genotypes, to select promising starting material for specific areas where new cultivars will be bred.

(C) O.M. Bezugla, L.N. Kobyzeva, N.M. Vus, P.M. Solonechnyi. 2020.

ISSN 1026-9959. Селекція і насінництво. 2020. Випуск 118. 
Materials and methods. To accomplish this purpose, environmental trials were conducted in 2015-2017 on the collection of bean accessions at four institutions in Ukraine, which differ by climatic characteristics. The eastern Forest-Steppe: Kharkiv region, Plant Production Institute nd. a. V.Ya. Yuriev of NAAS (PPI); southern Forest-Steppe: Poltava region, Ustymivka Experimental Station (UES) of Plant Production Institute nd. a. V.Ya. Yuriev of NAAS; Woodlands: Chernivtsi region, Bukovina State Agricultural Experimental Station (BSAES) of the Institute of Agriculture of the Carpathian Region of NAAS; southern Steppe: Odesa region, Plant Breeding and Genetics Institute - National Center of Seed and Cultivar Investigation (PBGI-NCSCI).

To assess the response of a genotype to an environment, depending on the weather peculiarities during the bean vegetation period, the hydrothermal coefficient (HTC) was used. The HTC was calculated from the formula (1):

$$
H T C=\frac{\sum r}{0.1 \times \sum t}
$$

where $\sum \mathrm{r}$ - is precipitation amount during the vegetation period, $\mathrm{mm} ; \sum \mathrm{t}-$ sum of temperatures above $10^{\circ} \mathrm{C}$ during the vegetation period, ${ }^{\circ} \mathrm{C} ; 0.1$ - coefficient.

The PBGI is situated in the steppe in the South ean daily air temperature is 15.6-22.6 C; the precipitation amount is $130 \mathrm{~mm}$. In 2015, the vegetation period was characterized by aboveaverage mean daily air temperature $\left(20.4^{\circ} \mathrm{C}\right)$, and the precipitation amount was significantly below the multiyear average $(83.8 \mathrm{~mm})$. Thus, the HTC was 0.45 , which is significantly lower than the optimum for the crop (1.00-1.10).

The UES and PPI are located in the Forest-Steppe of Ukraine; however, their multiyear average parameters during the bean vegetation period are different. The mean daily air temperature: UES $-15.5-20.5^{\circ} \mathrm{C}$, PPI $-15.6-21.3^{\circ} \mathrm{C}$. The precipitation amount: UES $-210 \mathrm{~mm}$, PPI $170 \mathrm{~mm}$. Accordingly, in 2015, the weather conditions during the crop vegetation period were different: at UES the mean daily air temperature reached the upper limit of the multiyear average $\left(20.5^{\circ} \mathrm{C}\right)$; the precipitation amount was above the multiyear average $(226.7 \mathrm{~mm})$; the HTC was 1.20 , which is higher than the optimum. At the PPI, the mean daily air temperature was close to the average $\left(19.6^{\circ} \mathrm{C}\right)$; the precipitation amount exceeded the multiyear average $(211 \mathrm{~mm})$; the HTC was not much higher than the optimum (1.17). It should be noted that precipitation was rain showers resulted in inopportune watering of plants.

BSAES is located in the Woodlands of Ukraine, where the multiyear average parameters during the bean vegetation period are as follows: the mean daily air temperature is $13.8-18.3^{\circ} \mathrm{C}$; the precipitation amount is $274 \mathrm{~mm}$. However, the mean daily temperatures during the crop vegetation period in 2015 exceeded the multiyear average by $>1{ }^{\circ} \mathrm{C}\left(19.5^{\circ} \mathrm{C}\right)$, and the precipitation was much below the average $(224.3 \mathrm{~mm})$; therefore, the HTC did not significantly exceed that at UES (1.24) (Table 1).

Table 1

The weather conditions in the sites of the environmental trials

\begin{tabular}{lccccc}
\hline \multirow{2}{*}{ Site } & \multicolumn{2}{c}{ Mean daily temperature ${ }^{\circ} \mathrm{C}$} & \multicolumn{2}{c}{ Precipitation amount mm } & Hydrothermal \\
\cline { 2 - 6 } & 2015 & $\begin{array}{c}\text { multiyear average } \\
\text { min-max }\end{array}$ & 2015 & multiyear average ${ }^{1)}$ & coefficient \\
\hline PBGI & 20.4 & $15.6-22.6$ & 83.8 & 130 & 0.45 \\
PPI & 19.6 & $15.6-21.3$ & 211 & 170 & 1.17 \\
UES & 20.5 & $15.5-20.5$ & 226.7 & 210 & 1.20 \\
BSAES & 19.5 & $13.8-18.3$ & 224.3 & 274 & 1.25 \\
\hline 1)
\end{tabular}

The model population consisting of 24 collection bean accessions with various responses to fluctuations in temperature and humidity in the environment, which were taken from the core 
collection of the National Centre for Plant Genetic Resources of Ukraine (NCPGRU), served as the test material to investigate the "genotype $\times$ environment" interaction. The accessions were sown with manual planters within the timeframe that is optimal for bean. The collection accessions were assessed in accordance with the valid classifier [11] and methodical recommendations for studying collection accessions of grain legumes [12]. The experimental data were statistically processed by analysis of variance in Microsoft office Excel. The environmental assessment of the genotypes was performed by GGE biplot method [13, 14, 15].

Results and discussion. When studying the "genotype $\times$ environment" interactions, several researchers $[16,17,18]$ noted a strong influence of the crop cultivation environment on the yield variability and emphasized that the "genotype" $(\mathrm{G})$ and the "genotype $\times$ environment" (GE) effects should be analyzed. GGE biplot using in the researches allows to graphical visualise their results. It promotes to concretize analysis of this observing $[13,19]$. A clear "genotype $\times$ environment" relationship was established by the GGE biplot method in studies on wheat [20], sorghum [21, 22, 23], soybean [24, 25] and bean [26, 27].

In 2015, the environmental trials of the model population of bean were conducted in four environments (PPI, UES, BSAES, PBGI) differing in the temperature-water regime during the period of growth and development of the crop.

On average, in the model population, the highest yields were obtained in the woodlands of Ukraine (BSAES) $-0.37 \mathrm{~kg}^{*} \mathrm{~m}^{-2}$. Moderate yields were registered in the forest-steppe of Ukraine: in the southern part (UES) $-0.28 \mathrm{~kg}^{*} \mathrm{~m}^{-2}$ and in the eastern part (PPI) $-0.19 \mathrm{~kg}^{*} \mathrm{~m}^{-2}$. The lowest yields were in the southern steppe of Ukraine (PBGI) $-0.07 \mathrm{~kg}^{*} \mathrm{~m}^{-2}$. There were accessions giving high yields in each environment. At the PPI, UD030076 $\left(0.38 \mathrm{~kg}^{*} \mathrm{~m}^{-2}\right)$, Holberg $\left(0.350 \mathrm{~kg}^{*} \mathrm{~m}\right.$ $\left.{ }^{2}\right)$ and UD030104 $\left(0.33 \mathrm{~kg}^{*} \mathrm{~m}^{-2}\right)$ gave the highest yields; at UES, such accessions were Dniprovska Bomba $\left(0.48 \mathrm{~kg}^{*} \mathrm{~m}^{-2}\right)$, Nadiia $\left(0.48 \mathrm{~kg}^{*} \mathrm{~m}^{-2}\right)$, Prelom $\left(0.45 \mathrm{~kg}^{*} \mathrm{~m}^{-2}\right)$ and Holberg $(0.44$ $\left.\mathrm{kg}^{*} \mathrm{~m}^{-2}\right)$; at BSAES - Mistseva Bomba $5\left(0.58 \mathrm{~kg}^{*} \mathrm{~m}^{-2}\right)$, Pervomaiska $\left(0.58 \mathrm{~kg}^{*} \mathrm{~m}^{-2}\right)$, Sperantsa $\left(0.54 \mathrm{~kg}^{*} \mathrm{~m}^{-2}\right)$ and Prelom $\left(0.50 \mathrm{~kg}^{*} \mathrm{~m}^{-2}\right)$; at the PBGI - Holberg $\left(0.14 \mathrm{~kg}^{*} \mathrm{~m}^{-2}\right)$ and Bukovinka $\left(0.10 \mathrm{~kg}^{*} \mathrm{~m}^{-2}\right)$ (Table 2).

Table 2

Seed yield of the bean accessions from the model population in different sites of the environmental trials, 2015

\begin{tabular}{|c|c|c|c|c|c|c|c|c|}
\hline \multirow[b]{2}{*}{$\begin{array}{l}\text { Geno- } \\
\text { type }\end{array}$} & \multirow{2}{*}{$\begin{array}{l}\text { Number of } \\
\text { the National } \\
\text { Catalogue } \\
\text { of Ukraine }\end{array}$} & \multirow[b]{2}{*}{ Name } & \multirow[b]{2}{*}{$\begin{array}{l}\text { Country } \\
\text { of origin }\end{array}$} & \multicolumn{5}{|c|}{ Seed weight $/ \mathrm{m}^{2}, \mathrm{~kg}$} \\
\hline & & & & PPI & UDE & BSAES & PBGI & average \\
\hline 1 & 2 & 3 & 4 & 5 & 6 & 7 & 8 & 9 \\
\hline G1 & UD0300025 & Pervomaiska & Ukraine & 0.16 & 0.16 & 0.58 & 0.06 & 0.24 \\
\hline $\mathrm{G} 2$ & UD0300045 & Prelom & Bulgaria & 0.16 & 0.45 & 0.50 & 0.02 & 0.28 \\
\hline G3 & UD0300076 & - & Moldova & 0.38 & 0.26 & 0.39 & 0.07 & 0.28 \\
\hline G4 & UD0300104 & - & Hungary & 0.33 & 0.38 & 0.41 & 0.09 & 0.30 \\
\hline G5 & UD0300152 & - & Ukraine & 0.07 & 0.12 & 0.24 & 0.07 & 0.12 \\
\hline G6 & UD0300227 & Holberg & USA & 0.35 & 0.44 & 0.40 & 0.01 & 0.30 \\
\hline G7 & UD0300238 & $\begin{array}{l}\text { Synelny- } \\
\text { kivska } 8\end{array}$ & Ukraine & 0.22 & 0.30 & 0.28 & 0.07 & 0.22 \\
\hline G8 & UD0300285 & $\begin{array}{l}\text { Belgorod- } \\
\text { skaia } 1\end{array}$ & Russia & 0.16 & 0.16 & 0.32 & 0.02 & 0.16 \\
\hline G9 & UD0300286 & - & Ukraine & 0.10 & 0.28 & 0.33 & 0.10 & 0.20 \\
\hline G10 & UD0300388 & $\begin{array}{c}\text { Mistseva Bom } \\
\text { ba } 5\end{array}$ & Ukraine & 0.05 & 0.25 & 0.58 & 0.01 & 0.22 \\
\hline G11 & UD0300397 & Sperantsa & Moldova & 0.23 & 0.34 & 0.54 & 0.08 & 0.30 \\
\hline G12 & UD0300413 & $\begin{array}{c}\text { Dniprovska } \\
\text { Bomba }\end{array}$ & Ukraine & 0.22 & 0.48 & 0.20 & 0.07 & 0.24 \\
\hline G13 & UD0300463 & - & Ukraine & 0.16 & 0.19 & 0.30 & 0.01 & 0.16 \\
\hline
\end{tabular}




\begin{tabular}{ccccccccc}
\hline 1 & 2 & 3 & 4 & 5 & 6 & 7 & 8 & 9 \\
\hline G14 & UD0300465 & - & Ukraine & 0.15 & 0.27 & 0.31 & 0.07 & 0.20 \\
G15 & UD0300775 & $\begin{array}{c}\text { Dokuchaev- } \\
\text { ska }\end{array}$ & Ukraine & 0.18 & 0.16 & 0.32 & 0.07 & 0.18 \\
G16 & UD0301092 & Yuvileina 287 & Ukraine & 0.19 & 0.20 & 0.40 & 0.05 & 0.21 \\
G17 & UD0301094 & Nadiia & Ukraine & 0.19 & 0.48 & 0.41 & 0.09 & 0.29 \\
G18 & UD0303258 & Perlyna & Ukraine & 0.10 & 0.21 & 0.44 & 0.10 & 0.21 \\
G19 & UD0303351 & Otrada & Ukraine & 0.22 & 0.25 & 0.44 & 0.10 & 0.25 \\
G20 & UD0303441 & Bukovinka & Ukraine & 0.06 & 0.23 & 0.43 & 0.10 & 0.20 \\
G21 & UD0303568 & Nespodivanka & Ukraine & 0.26 & 0.27 & 0.35 & 0.06 & 0.24 \\
G22 & UD0303753 & Veselka & Ukraine & 0.16 & 0.28 & 0.28 & 0.09 & 0.20 \\
G23 & UD0303805 & Bogema & Nitherlands & 0.09 & 0.19 & 0.42 & 0.07 & 0.19 \\
G24 & UD0303971 & Panna & Ukraine & 0.14 & 0.29 & 0.32 & 0.08 & 0.21 \\
& & & LSD 005 & 0.05 & 0.06 & 0.06 & 0.02 & \\
& & Average & & 0.18 & 0.28 & 0.38 & 0.06 & \\
\hline
\end{tabular}

1) - genotype designation for visualization of the environmental trial data

The GGE biplot polygon (Figure 1) shows patterns of the "genotype $\times$ environment" relationship. The polygon is divided into sectors. The genotype that is the most adapted to the growing conditions of an environmental trial site is located at the top of the polygon in the same sector with the test marker [14]. We identified genotypes that are the most adapted to these environments: to the forest-steppe - Holberg (G6); to the woodlands - Mistseva Bomba 5 (G10) and Pervomaiska (G1); to the southern Steppe - Holberg (G6).

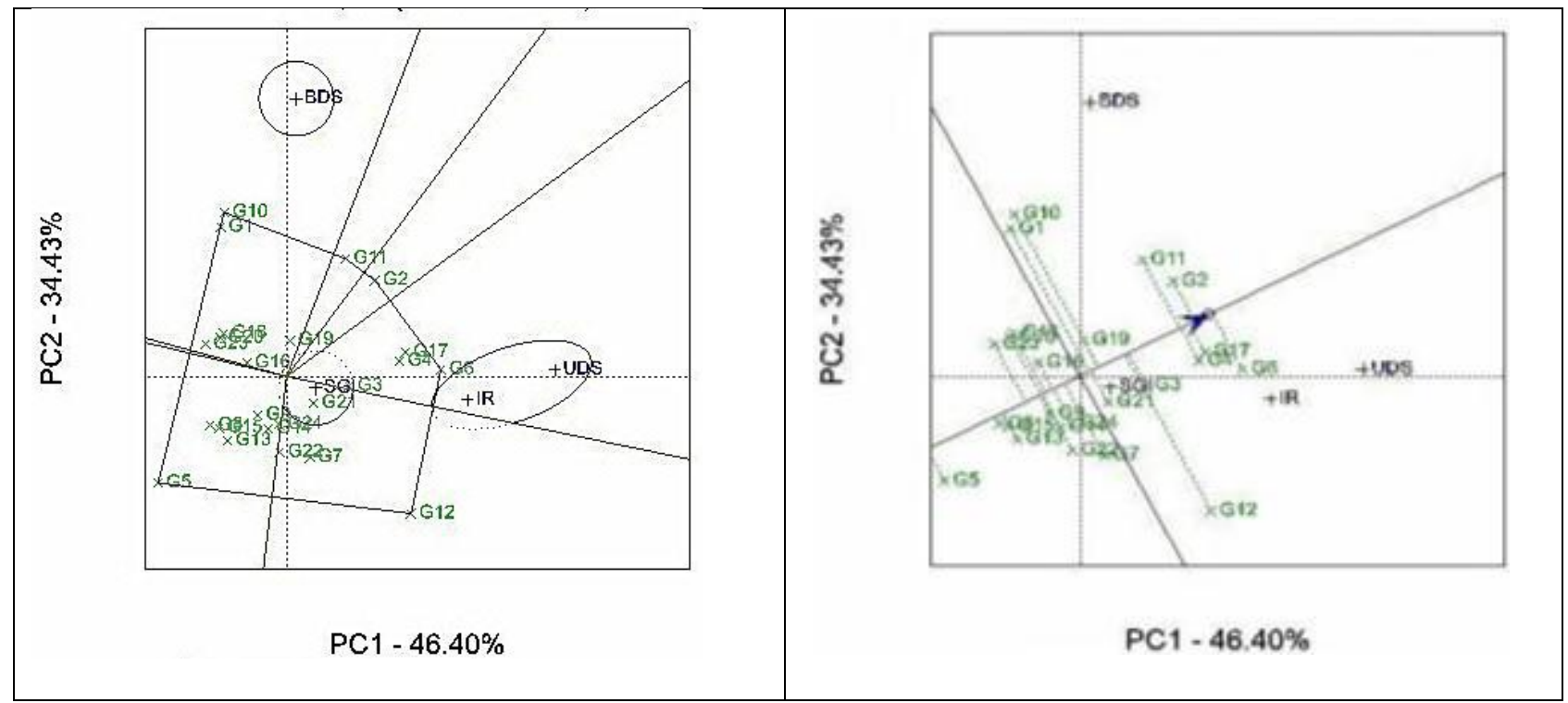

Figure 1. GGE biplot, "Which-Won-Where"

Figure 2. GGE biplot, "mean vs. stability"

In the environments where the limiting factor for the bean growth and development is water deficit during the crop vegetation period (PPI, UES and PBGI), drought-tolerant Holberg, giving a high yield of seeds, is advantageous.

Upon excess water (BES), genotypes with high potential yields, however with low stability of yields, which depend on the environment and respond positively to favourable for bean conditions of cultivation, are advantageous: Pervomaiska and Mistseva Bomba 5.

Thus, when selecting starting material for hybridization in the woodlands of Ukraine, one should give priority to genotypes with high potential yields, and in the forest-steppe and steppe of Ukraine - to highly drought-tolerant genotypes with stable yields of seeds. 
To analyse the genotypes' responses to various environmental conditions, the GGE biplot "mean vs. stability" (Figure 2), which is based on their average yields and stability in the environment trial sites, was used. The line passing through the biplot origin and the average environment is called the average environment coordinate (AEC) axis or the yield line. The arrow shows the direction of yield growth. Another axis, perpendicular to the AEC axis, is the stability line dividing the genotypes into highly and poorly stable ones. Accessions with the shortest projection lengths on this axis are considered the most stable (Solonechnyi et al., 2014). Stable genotypes and genotypes with high potential yields were identified. Among them, there are valuable genotypes with high yields of seeds and high stability of yields - Nadiia (G17), Prelom (G2), UD0300104 (G4); genotypes with high potential yields - Dniprovska Bomba (G12), Mistseva Bomba 5 (G 10), and Pervomaiska (G1).

The "ideal" genotype is a stable genotype with a high average yield, which has a wide range of adaptive characteristics. To find genotypes combining high yields and stability, the GGE biplot comparing the genotypes with the "ideal" one was used (Figure 3).

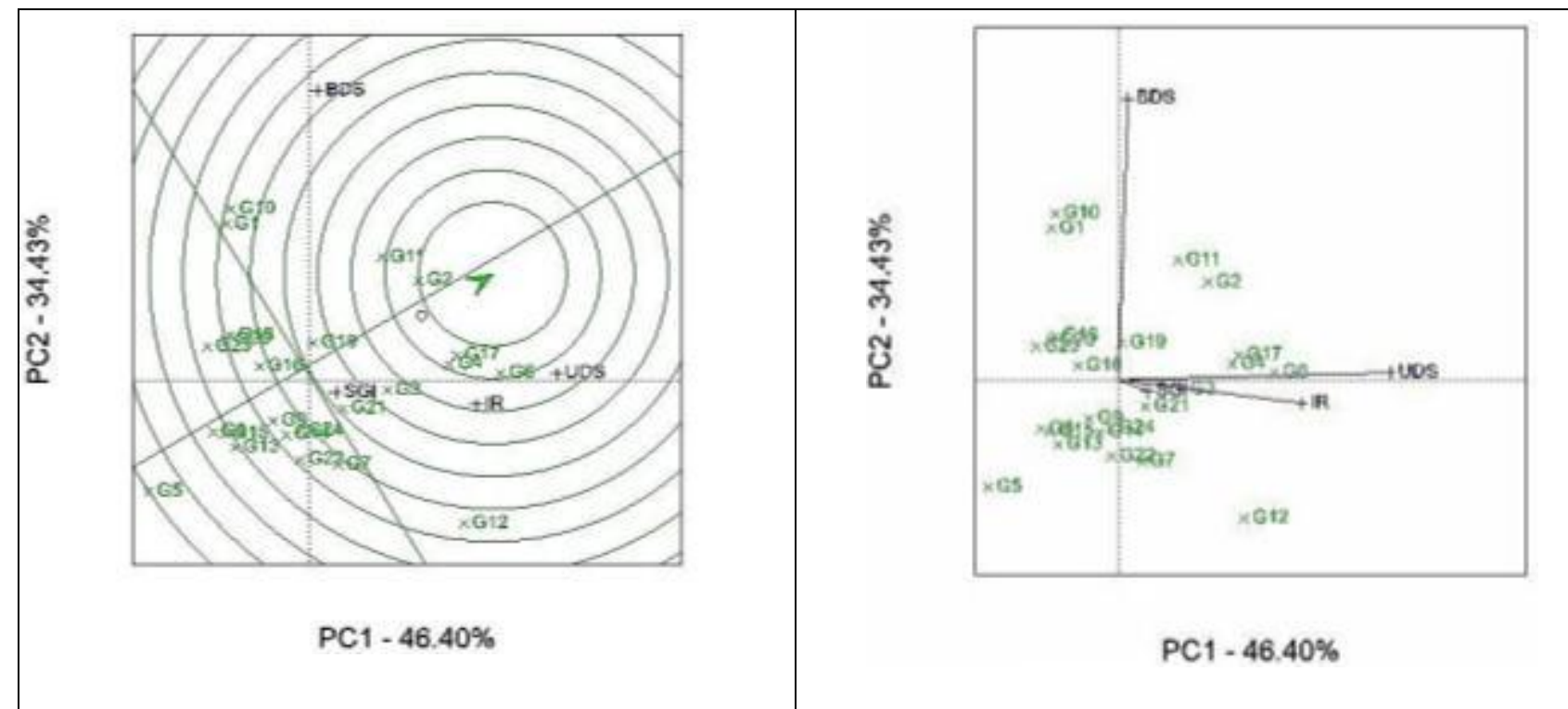

Figure 3. GGE biplot, comparison of the genotypes under investigation with the "ideal" genotype
Figure 4. GGE biplot, discriminating and representative capacities of the environments

The center of the circles shows the position of the "ideal" genotype. The closer the genotype projection to the center of the circles is, the closer the genotype under investigation to the "ideal" one is (Solonechnyi et al., 2015; Solonechnyi, 2017; Solonechnyi et al., 2018). These are the following collection accessions: Holberg (G6) (with the average seed yield of $0.33 \mathrm{~kg}^{*} \mathrm{~m}^{-2}$ ), Prelom (G2) (0.28 kg*m $\mathrm{kg}^{-2}$ ), Nadiia (G17) $\left(0.29 \mathrm{~kg}^{*} \mathrm{~m}^{-2}\right)$, UD0300104 (G4) (0.30 kg*m-2), and Sperantsa (G11) $\left(0.30 \mathrm{~kg}^{*} \mathrm{~m}^{-2}\right)$. The distinguished genotypes are highly resistant to Fusarium (Fusarium Link.) infection, viruses (bean common mosaic virus, bean yellow mosaic virus, Nicotiana virus) and bacterial wilt (Corynebacterium flaccumfaciens (Halges) Dowson), tolerant to bacterial spots Xanthomonas phaseoli (E. Smith) Dowson, Xanthomonas phaseoli v. fuskans Burkholder, Pseudomonas medicaginis (Sackelt) v. phaseolicola (Burclh), Pseudomonas vignae Gardener et Kendrick). Holberg is the most valuable genotype, especially for the forest-steppe of Ukraine, since it is characterized by high drought tolerance. We recommend it as a reference accession for yield (Table 2).

Prelom is the most adapted to mechanized harvesting. Its plants are bushy with indeterminate growth and above-average resistance to lodging. Sperantsa has seeds of an above-average size (1000-seed weight is $0.30 \mathrm{~kg}$ ). UD0300104 is the earliest ripening (the vegetation period is 73 days) (Table 3 ). 
Table 3

Characteristics of the genotypes that are close to the "ideal" genotype according to the results of the trials in the eastern forest-steppe of Ukraine, 2015-2017

\begin{tabular}{ccccc}
\hline Genotype & $\begin{array}{c}\text { Vegetation period, } \\
\text { days }\end{array}$ & $\begin{array}{c}\text { Plant type } \\
\text { score }^{1)}\end{array}$ & $\begin{array}{c}\text { Lodging resistance } \\
\text { score }^{2)}\end{array}$ & $\begin{array}{c}\text { 1000-seed weight } \\
\mathrm{kg}\end{array}$ \\
\hline Holberg & 76 & 3 & 3 & 0.26 \\
Prelom & 80 & 1 & 6 & 0.21 \\
Nadiia & 76 & 3 & 5 & 0.23 \\
UD030104 & 73 & 1 & 5 & 0.24 \\
Sperantsa & 79 & 3 & 3 & 0.30 \\
\hline
\end{tabular}

1) -1 - bushy, 3 - bushy with nutating top; ${ }^{2)}-3$ - high, 5 - moderate, 6 - above-moderate

Fan et al. [28] used GGE biplot analysis to assess the discriminating and representative capacities of environments. Due to this method, the testing environments that are more informative for assessing the adaptability of the collection accessions were identified (Figure 4). The vector length is directly proportional to the standard deviation of the genotype yield in this environment. If the testing environment marker is close to the biplot center, i.e. has a short vector, all the genotypes have similar yields, so this environment is not informative for the differentiation of genotypes. A small angle between the environment vector indicates a strong correlation between the genotype yields in these environments [29, 30]. Thus, the GGE biplot categorized the testing sites of the environment trials into three groups.

Group I includes the PBGI site (southern Steppe of Ukraine) with a short vector, which indicates a low informativity of this environment about the genotypes under investigation. The accessions grown in this site gave similar yields (Table 2). This is a region with high summer temperatures and water deficit. Consequently, all the genotypes were suppressed by drought and heat, which made it impossible to determine the whole range of their adaptive features. However, we identified genotypes with high drought- and heat-tolerance: Holberg (G6) and Bukovinka (G20), which gave the highest yields in this environment.

Group II includes the site with a long vector and a large angle with the AEC axis BSAES (Woodlands of Ukraine). This environment has the highest discriminating capacity, which does not allow evaluating genotypes in terms of the whole range of adaptive features, either. Excess water prevents from determining the level of drought tolerance - a trait that limits the bean cultivation in Ukraine. In this environment, the intensive genotypes were chosen: Pervomaiska, Mistseva Bomba 5, Sperantsa and Prelom, which gave seed yields of over 0.50 $\mathrm{kg}^{*} \mathrm{~m}^{-2}$ (Table 2).

Group III includes the environments that have long vectors and moderate yields (eastern and southern forest-steppe of Ukraine - PPI and UES, respectively) and are the most informative for assessing the adaptability of genotypes. These sites of the environment trials are located in the moderately moistened zone and allow evaluating genotypes for stability of seed yields.

Thus, the GGE biplot analysis of the environments singled out the most informative sites of the environment trials, where the study of the genotypes was continued in 2015-2017: PPI eastern Forest-Steppe of Ukraine and UES - southern Forest-Steppe.

The weather during the bean vegetation period in 2015-2017 differed both between the sites of the environment trials (eastern Forest-Steppe - PPI and southern Forest-Steppe - UES) and between the study years (Figure 5).

2015 was the most favourable year (HTC: PPI - 1.17, UES - 1.20). The 2016 hydrothermal balance at UES was close to optimal (HTC $=0.97)$, whereas the PPI site was waterlogged $(\mathrm{HTC}=1.88)$, which caused severe damage of bean plants by Fusarium and bacterial infections. In 2017, there was a water deficit for the crop growth and development (HTC: PPI - 0.28, UES 0.73 ), especially at the PPI. This accordingly affected the average yield throughout the genotypes: in 2015 PPI $-0.20 \mathrm{~kg}^{*} \mathrm{~m}^{-2}$, UES $-0.26 \mathrm{~kg}^{*} \mathrm{~m}^{-2}$; in $2016 \mathrm{PPI}-0.17 \mathrm{~kg}^{*} \mathrm{~m}^{-2}$, UES $-0.22 \mathrm{~kg}^{*} \mathrm{~m}^{-2}$; in $2017 \mathrm{PPI}-0.14 \mathrm{~kg}^{*} \mathrm{~m}^{-2}$, UES $-0.18 \mathrm{~kg}^{*} \mathrm{~m}^{-2}$. 


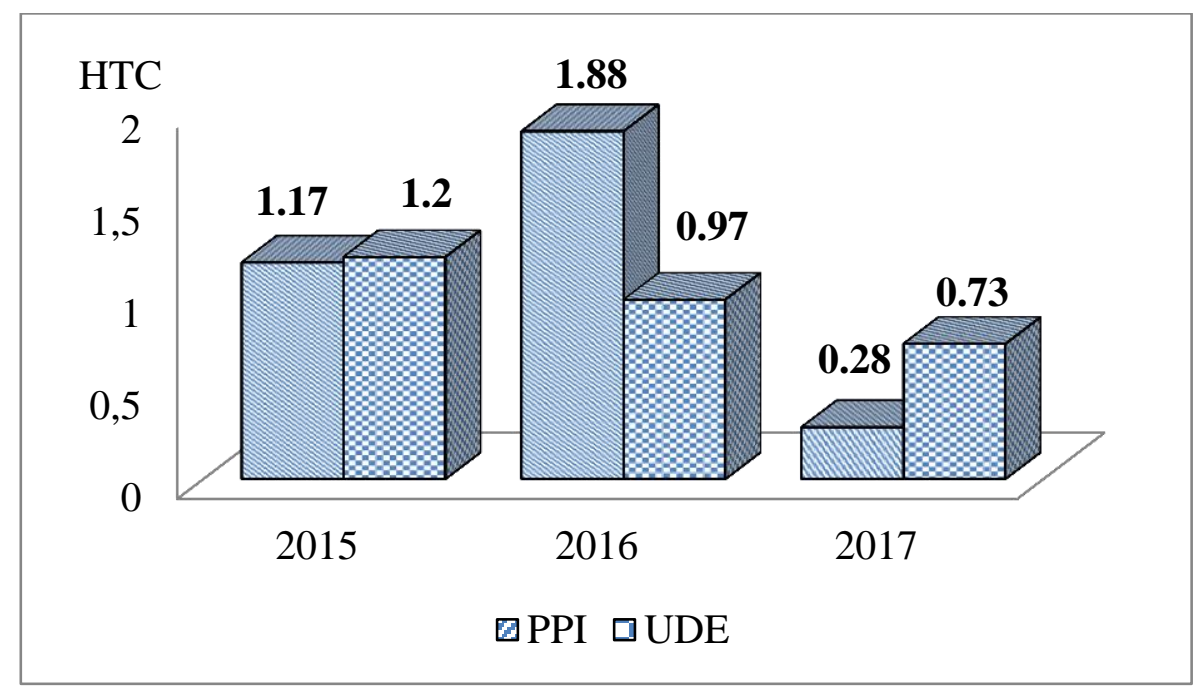

Figure 5. The weather in the eastern (PPI) and southern (UES) Forest-Steppe of Ukraine

Thus, the informative environments have different characteristics: the weather in the eastern Forest-Steppe of Ukraine is rougher for the bean growth and development than that in the southern Forest-Steppe. The temperature/moisture ratio in the eastern Forest-Steppe varied greatly $(\mathrm{HTC}=0.28-1.88)$, whereas in the southern Forest-Steppe the hydrothermal balance was more stable $(\mathrm{HTC}=0.73-1.20)$.

As a result of the three-year study, we identified the most productive genotypes: for the eastern Forest-Steppe of Ukraine (PPI) - UD0300076 (G3) $\left(0.36 \mathrm{~kg}^{*} \mathrm{~m}^{-2}\right)$, Holberg (G6) (0.31 $\left.\mathrm{kg}^{*} \mathrm{~m}^{-2}\right)$ and UD0300104 (G4) $\left(0.36 \mathrm{~kg}^{*} \mathrm{~m}^{-2}\right)$; for the southern Forest-Steppe (UES) - Holberg (G6) $\left(0.36 \mathrm{~kg}^{*} \mathrm{~m}^{-2}\right.$, Dniprovska Bomba (G12) $\left(0.34 \mathrm{~kg}^{*} \mathrm{~m}^{-2}\right)$, UD0300104 (G4) $\left(0.31 \mathrm{~kg}^{*} \mathrm{~m}^{-2}\right)$ and Nespodivanka (G21) $\left(0.31 \mathrm{~kg}^{*} \mathrm{~m}^{-2}\right)$ (Table 4).

Table 4

Bean seed yield in the eastern (PPI) and southern (UES) forest-steppe of Ukraine

\begin{tabular}{|c|c|c|c|c|c|c|c|c|c|}
\hline \multirow{3}{*}{ Genotype } & \multirow{3}{*}{ Name } & \multicolumn{8}{|c|}{ Bean seed yield $\mathrm{kg}^{*} \mathrm{~m}^{-2}$} \\
\hline & & \multicolumn{4}{|c|}{ PPI } & \multicolumn{4}{|c|}{ UES } \\
\hline & & 2015 & 2016 & 2017 & average & 2015 & 2016 & 2017 & average \\
\hline G1 & Pervomaiska & 0.16 & 0.04 & 0.02 & 0.07 & 0.16 & 0.18 & 0.14 & 0.16 \\
\hline G2 & Prelom & 0.16 & 0.22 & 0.07 & 0.15 & 0.45 & 0.18 & 0.12 & 0.25 \\
\hline G3 & UD0300076 & 0.38 & 0.48 & 0.21 & 0.36 & 0.26 & 0.13 & 0.13 & 0.17 \\
\hline G4 & UD0300104 & 0.33 & 0.27 & 0.23 & 0.28 & 0.38 & 0.35 & 0.21 & 0.31 \\
\hline G5 & UD0300152 & 0.07 & 0.07 & 0.07 & 0.07 & 0.12 & 0.10 & 0.08 & 0.10 \\
\hline G6 & Holberg & 0.35 & 0.28 & 0.31 & 0.31 & 0.44 & 0.32 & 0.33 & 0.36 \\
\hline G7 & Synelnykivska 8 & 2.22 & 0.20 & 0.16 & 0.19 & 0.30 & 0.20 & 0.14 & 0.21 \\
\hline G8 & Belgorodskaia 1 & 0.16 & 0.13 & 0.19 & 0.16 & 0.16 & 0.16 & 0.12 & 0.15 \\
\hline G11 & Sperantsa & 0.23 & 0.21 & 0.17 & 0.20 & 0.10 & 0.06 & 0.27 & 0.14 \\
\hline G12 & Dniprovska Bomba & 0.22 & 0.22 & 0.17 & 0.20 & 0.48 & 0.29 & 0.26 & 0.34 \\
\hline G15 & Dokuchaevska & 0.18 & 0.04 & 0.02 & 0.08 & 0.16 & 0.29 & 0.24 & 0.23 \\
\hline G16 & Yuvileina 287 & 0.19 & 0.15 & 0.20 & 0.18 & 0.20 & 0.10 & 0.14 & 0.15 \\
\hline G17 & Nadiia & 0.19 & 0.16 & 0.15 & 0.17 & 0.40 & 0.25 & 0.16 & 0.27 \\
\hline G19 & Otrada & 0.22 & 0.20 & 0.15 & 0.19 & 0.25 & 0.26 & 0.19 & 0.23 \\
\hline G21 & Nespodivanka & 0.26 & 0.23 & 0.12 & 0.20 & 0.27 & 0.39 & 0.26 & 0.31 \\
\hline G22 & Veselka & 0.16 & 0.12 & 0.10 & 0.13 & 0.28 & 0.21 & 0.22 & 0.24 \\
\hline G23 & Bogema & 0.09 & 0.05 & 0.09 & 0.08 & 0.19 & 0.13 & 0.09 & 0.14 \\
\hline G24 & Panna & 0.14 & 0.21 & 0.15 & 0.17 & 0.29 & 0.40 & 0.21 & 0.30 \\
\hline \multirow[t]{3}{*}{$\mathrm{G} 25$} & N 201-15 & 0.19 & 0.04 & 0.01 & 0.08 & 0.06 & 0.21 & 0.08 & 0.12 \\
\hline & Average & 0.20 & 0.17 & 0.14 & & 0.26 & 0.22 & 0.18 & \\
\hline & $\mathrm{LSD}_{005}$ & 0.05 & 0.06 & 0.04 & & 0.07 & 0.06 & 0.04 & \\
\hline
\end{tabular}


The GGE biplot analysis showed that the most stable seed yields were obtained from Holberg (G6), Otrada (G19), UD0300104 (G4), Bogema (G23), UD0300152 (G5), N 201-15 (G25) and Synelnykivska 8 ( G7) (Figure 6). Holberg and UD0300104 were close to the "ideal" genotype (Figure 7).

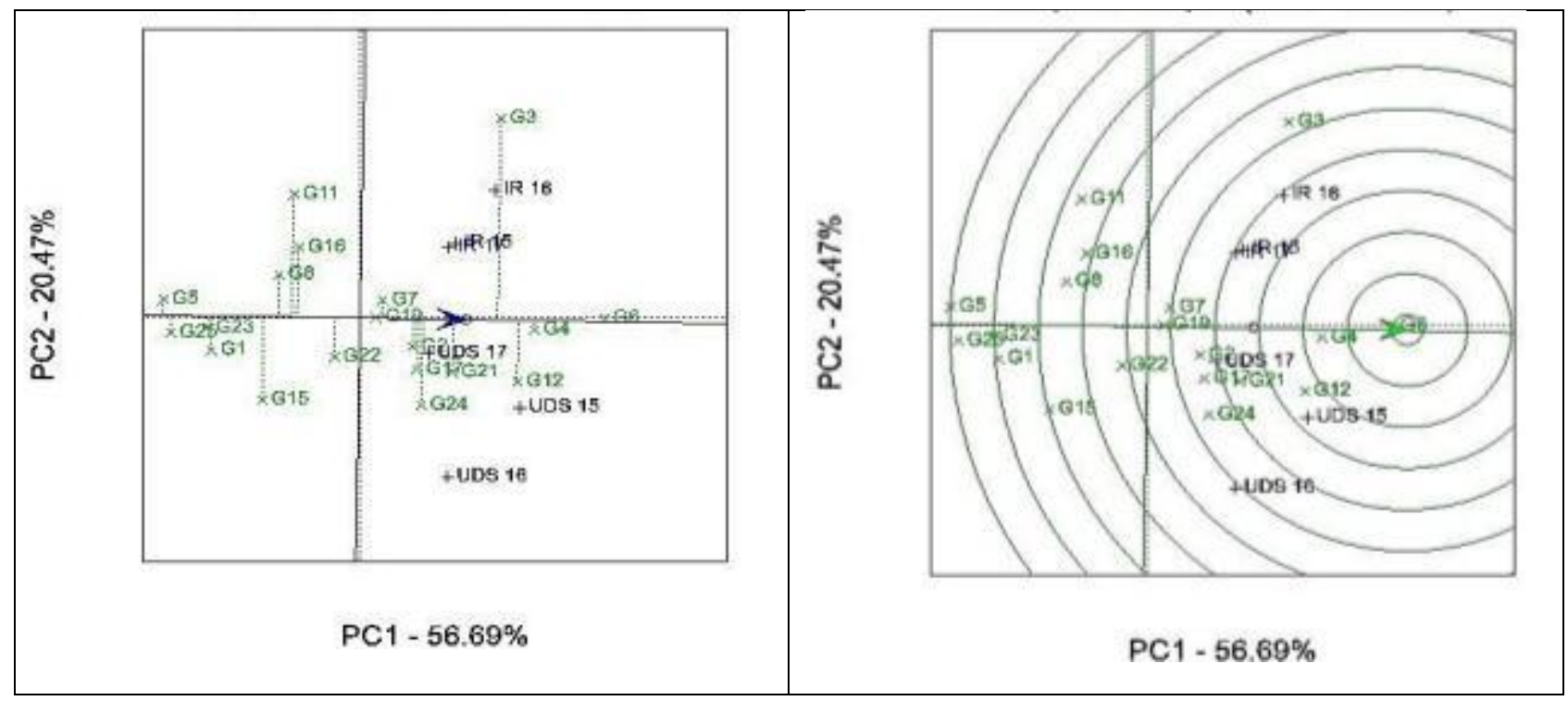

Figure 6. GGE biplot, "mean vs. stability"

Figure 7. GGE biplot, genotypes close to the "ideal" genotype

Conclusions. The environment trials of the bean genotypes at the sites differing in the climatic conditions ensured comparison of their informativity. It was established that the southern Steppe (PBGI) and Woodlands of Ukraine (BSAES) did not allow a full assessment of the adaptive potentials of the genotypes due to the extreme for bean weather during its vegetation period: at the PBGI site, it is high temperatures and water deficit in summer; at the BES site - excess water. However, these environments are necessary for evaluating drought- and heat-tolerance (PBGI) as well as for identification of genotypes with high potential yields (BSAES). The weather conditions in the eastern (PPI) and southern (UES) Forest-Steppe of Ukraine, which make it possible to assess genotypes in terms of stability of their seed yields, are the most informative for assessing the adaptability of the genotypes.

When developing cultivars for different zones of Ukraine, one should select parents, taking into account their responses to the weather: for the South of Ukraine (PBGI) - droughttolerant genotypes with high heat tolerance (Holberg); for the Woodlands (BSAES) - intensive genotypes (Mistseva Bomba 5, Pervomaiska); for the Forest-Steppe (PPI and UES) - stable genotypes with high drought tolerance (Holberg, Nadiia, UD0300104).

The study of the bean genotypes in the Forest-Steppe of Ukraine (PPI and UES) revealed that the following genotypes gave the most stable yields of seeds: Holberg, Otrada, UD0300104, Bogema, UD0300152, N 201-15 and Synelnykivska 8; of them Holberg, Otrada, UD0300104 and Synelnykivska 8 are noticeable for high yields. Holberg and UD0300104 were close to the "ideal" genotype.

Acknowledgments. We are deeply grateful to the teams that participated in the environment trials in compliance with all methodological requirements: the Department of Legume Breeding, Genetics and Seed Production of the Plant Breeding and Genetics Institute - National Center of Seed and Cultivar Investigation and personally to Candidate of Agricultural Sciences Oleh Volodymyrovych Bushulian and Candidate of Biological Sciences Halyna Dmytrivna Lavrova; to the Laboratory of Grain Legumes, Groat Crops and Corn of Ustymivka Experimental Station of Plant Production of Yuriev Plant Production Institute and personally to Candidate of Agricultural Sciences Serhei Ivanovych Sylenko; to the Laboratory of Grain Legumes of the Bukovina State Agricultural Experimental Station of the Institute of Agriculture of the Carpathian 
Region and personally to Candidate of Agricultural Sciences, Honored Worker of Agriculture Mariia Hryhorivna Holokhorynska.

\section{References}

1. Hagos HG, Abay F. AMMI and GGE biplot analysis of bread wheat genotypes in the northern part of Ethiopia. Journal of Plant Breeding and Genetics. 2013; 01: 12-18.

2. Morsi A, Abdel-Raham RA, Fares WM, Hasari A. Interpretation of genotype x environment interaction for soybean variety trials using different stability procedures. WRB. 2017. URL: https://www.researchgate.net/publication/332986588_INTERPRETATION_OF_GENOTYPE _X_ENVIRONMENT_INTERACTION_FOR_SOYBEAN_VARIETY_TRIALS_USING_DI FFERENT_STABILITY_PROCEDURES.

3. Merezhko AF. Principles of search for, development and use of donors of valuable trains in plant breeding. Identifitsirovannyy Genofond Rasteniy i Selektsiya. St-Petersburg, 2005. P. 189-204

4. Pourdad SS, Moghaddam MJ. Study on seed yield stability of sunflower inbred lines through GGE biplot. HELIA. 2013; 36(58): 19-28. DOI: 1018-1806/2013/1018-18061358019P.

5. Kazydub NG, Marakaeva TV. Comparative assessment of economic and valuable signs of samples of haricot (Phaseolus vulgaris L.) and creation on their basis of new selection material for conditions of the southern forest-steppe of the Western Siberia. Omsk, 2015. $150 \mathrm{p}$.

6. Bezugla OM, Kobyzeva LN. Plant genetic resources in solving bean breeding challenges. Zbirnyk Naukovykh Prats Selektsiino-Henetychnoho Instytutu - Natsionalnoho Tsentru Nasinnytstva ta Sortovyvchennia. 2015; 26(66): 74-86.

7. Kobyzeva LN, Bezugla OM, Vus NO, Biryukova OV, Tertyshnyi OV. The genetic resources of grain legumes and millet with resistance to abiotic factors. In: Osnovy Upravlinnia Produktsiinym Protsesom Polevykh Kultur. Kharkiv, 2016. P. 70-96.

8. Bezugla OM, Kobyzeva LN. Scientific principles of formation of a trait collection of common bean (Phaseolus vulgaris L.). Genetychni Resursy Roslyn. 2014; 14: 50-61.

9. Bezuglaia ON. Adaptive potential of collection bean accessions. Maslichnyye Kultury. 2017; 4(172): 23-28.

10. WRB. Pogoda i klimat. 2018. http://www.pogodaiklimat.ru/.

11. Bezugla OM, Kobyzeva LN, Ryabchun VK, Drepin IM, Izhik MK, Sokol TV, Duplyak O. Wide unified descriptors list of the genus Phaseolus L. Kharkiv, 2004. 50 p.

12. Kobyzeva LN, Bezugla OM, Sylenko SI, Kolotilov VV, Sokol TV, Dokukina KI, Vasylenko AO, Bezuglyi IM, Vus NO. Methodical recommendations for studying the genetic resources of grain legumes. Kharkiv, 2016. $84 \mathrm{p}$.

13. Yan W, Kang MS. GGE biplot analysis: a graphical tool for breeders, geneticists and agronomists. CRC Press, Boca Raton, FL, 2003.

14. Yan W, Tinker NA. Analyse par double projection des résultats des essais multienvironnementaux: principes et applications. Canadian Journal of Plant Science. 2006; 86: 623-645.

15. Solonechnyi P, Kozachenko M, Vasko N, Gudzenko V, Ishenko V, Kozelets G, Logvinenko Y, Vinyukov A. AMMI and GGE biplot analysis of yield performance of spring barley (Hordeum vulgare L.) varieties in multi environment trials. Agriculture and Forestry. 2018; 64(1): 121-132. DOI: 10.17707/AgricultForest.64.1.15.

16. Gauch HG. Statistical analysis of yield trials by AMMI and GGE. Crop Science. 2006; 46: 1488-1500. DOI: 10.2135/cropsci2005.07-0193.

17. Yan W, Kang MS, Ma B, Woods PL, Cornelius PL. GGE biplot vs. AMMI analysis of genotype - by-environment data. Crop Science. 2007; 47: 643-655. DOI: 10.2135/cropsci2006.06.0374.

18. Solonechnyi PN. AMMI and GGE biplot analyses of genotype-environment interaction in spring barley lines. Vavilov Journal of Genetics and Breeding. 2017; 21(6): 657-662. DOI: 10.18699/VJ17.283. 
19. Mohammadi R, Amri A. Genotype $\times$ environment interaction and genetic improvement for yield and yield stability of rainfed durum wheat in Iran. Euphytica. 2013; 192(2): 227-249. DOI: 10.1007/s10681-012-0839-1.

20. Kadir M, Kaimuddin M, Forid B, Nusa Y. GGE-biplot analysis of yield stability in environment trial of tropical wheat (Triticum aestivum L.) genotype under dry season in Indonesia. Research on Crops. 2018; 19(4): 680-688.

21. Aruna C., Rakshit S, Shrotria PK, Pahuja S, Jain SK, Siva Kumar S, Modi ND, Deshmukh DT, Kapoor R, Patil JV. Assessing genotype-by-environment interactions and trait associations in forage sorghum using GGE biplot analysis. The Journal of Agricultural Science. 2015; 1(1): 73-86. DOI: 10.1017/S0021859615000106.

22. Mare M, Manjeru P, Ncube B, Sisito G. GGE biplot analysis of genotypes by environment interaction on Sorghum bicolor L. (Moench) in Zimbabwe. African Journal of Plant Science. 2017; 11(7): 308-319. DOI: 10.5897/AJPS2017.1538

23. Seyoum A, Gebreyohannes A, Nega A, Nida H, Tadesse T, Tirfessa A, Bejiga T. Performance evaluation of Sorghum (Sorghum bicolor (L.) Moench) genotypes for grain yield and yield related traits in drought prone areas of Ethiopia. Advances in Crop Science and Technology. 2019; 7(2): 423.

24. Qin J, Xu R, Li H, Yang C. Evaluation of productivity and stability of elite summer soybean cultivars in multi-environment trials. Euphytica. 2015; 206(3): 759-773. DOI: 10.1007/s10681-015-1513-1.

25. Bhatiya A, Aditya JP, Kumari V, Kishore N. GGE biplot \& ammi analysis of yield stability in multi-environment trial of soybean [Glycine max (L.) Merrill] genotypes under rainfed condition of north western Himalayan hills. Indian Journal of Genetics and Plant Breeding. 2017; 27(1): 227-238.

26. Mathobo R, Marais D. Evaluation of genotype $\mathrm{x}$ environment interaction using GGE-biplot on dry beans (Phaseolus vulgaris L.) in Limpopo province of South Africa. Australian Journal of Crop Science. 2017; 11(05): 506-515. DOI: 10.21475/ajcs.17.11.05.p303.

27. Oliveira TRA, Gravina GA, Oliveira GHF, Araújo KC, Araújo LC, Daher RF, Vivas M, Gravina LM, Cruz DP. The GT biplot analysis of green bean traits. Ciencia Rural. 2018; 48(6). DOI: 10.1590/0103-8478cr20170757.

28. Fan XM, Kang MS, Chen H, Zhang Y, Tan J, Xu C. Yield stability of maize hybrids evaluated in multi-environment trials in Yunnan, China. Agronomy Journal. 2007; 99(1): 220-228. DOI: 10.2134 /agroj2006.0144.

29. Solonechnyi PM, Kozachenko MR, Vasko NI, Naumov OG, Vazhenina OE, Solonechna OV, Dmitrenko PP, Kovalenko AI. GGE biplot analysis of genotype - environment interaction in spring barley varieties. Sel. Nasinn. 2014; 106: 93-102. DOI: 10.30835/24137510.2014.42134.

30. Solonechnyi P, Vasko N, Naumov A, Solonechnaya O, Vazhenina O, Bondareva O, Logvinenko Y. GGE biplot analysis of genotype by environment interaction of spring barley varieties. Zemdirbyste-Agriculture. 2015; 102(4): 431-436. DOI: 10.13080/z-a.2015.102.055.

\section{Список використаних джерел}

1. Hagos H.G., Abay M. AMMI and GGE biplot analysis of bread wheat genotypes in the northern part of Ethiopia. Journal of Plant Breeding and Genetics. 2013. No 01. P. 12-18.

2. Morsi A., Abdel-Raham R.A., Fares W.M., Hasari A. Interpretation of genotype x environment interaction for soybean variety trials using different stability procedures. WRB, 2017. https://www.researchgate.net/publication/332986588_INTERPRETATION_OF_GENOTYPE _X_ENVIRONMENT_INTERACTION_FOR_SOYBEAN_VARIETY_TRIALS_USING_D IFFERENT_STABILITY_PROCEDURES.

3. Мережко А.Ф. Принципы поиска, создания и использования доноров ценных признаков в селекции растений. Идентифицированный генофонд растений и селекция. С.Петербург: INIIR, 2005. C. 189-204. 
4. Pourdad S.S., Moghaddam M.J. Study on seed yield stability of sunflower inbred lines through GGE biplot. HELIA. 2013. No 36(58). P. 19-28.

5. Kazydub N.G. Marakaeva T.V. Comparative assessment of economic and valuable signs of samples of haricot (Phaseolus vulgaris L.) and creation on their basis of new selection material for conditions of the southern forest-steppe of the Western Siberia. Monograph. Omsk, 2015. 150 p. (in Russian).

6. Безугла О.М., Кобизєва Л.Н. Генетичні ресурси рослин у вирішенні проблем селекції квасолі. Збірник наукових праць селекційно-генетичного інституту - Національного центру насінництва і сортовивчення. 2015. № 26 66). С. 74-86.

7. Кобизєва Л.Н., Безуглаа О.М., Вус Н.О., Бірюкова О.В., Тертишний О.В. Генетичні ресурси зернобобових культур і проса з ознаками стійкості до абіотичних чинників. Основи управління продуккійним процесом польових культур. Харків, 2016. С. 70-96.

8. Безугла О.М., Кобизєва Л.Н. Наукові основи формування ознакової колекції квасолі звичайної (Phaseolus vulgaris L.). Генетичні ресурси рослин. 2014. № 14. С. 50-61.

9. Безуглая О.Н. Адаптивный потенциал коллекционных образцов фасоли. Масличные культуры. 2017. № 4(172). С. 23-28.

10. WRB. Pogoda i klimat. 2018. http://www.pogodaiklimat.ru/

11. Безугла О.М., Кобизєва Л.Н., Рябчун В.К., Дрепін І.М., Іжик М.К., Сокол Т.В., Дупляк О.T. Широкий уніфікований класифікатор України роду Phaseolus L. Харків, 2004. 50 с.

12. Кобызева Л.Н., Безугла О.М., Силенко С.І., Колотілов В.В., Сокол Т.В., Докукіна К.І., Василенко А.О., Безуглий I.М., Вус Н.О. Методичні рекомендації з вивчення генетичних ресурсів зернобобових культур. Харків, 2016. 84 с..

13. Yan W., Kang M.S. GGE biplot analysis: a graphical tool for breeders, geneticists and agronomists. CRC Press, Boca Raton, FL, 2003.

14. Yan W., Tinker N.A. Analyse par double projection des résultats des essais multienvironnementaux: principes et applications. Canadian Journal of Plant Science. 2006. No 86. P. 623-645.

15. Solonechnyi P., Kozachenko M., Vasko N., Gudzenko V., Ishenko V., Kozelets G., Logvinenko Yu., Vinyukov A. AMMI and GGE biplot analysis of yield performance of spring barley (Hordeum vulgare L.) varieties in multi environment trials. Agriculture and Forestry. 2018. No 64(1). P. 121-132. DOI: 10.17707/AgricultForest.64.1.15.

16. Gauch H.G. Statistical analysis of yield trials by AMMI and GGE. Crop Science. 2006. No 46. P. 1488-1500. DOI: 10.2135/cropsci2005.07-0193.

17. Yan W., Kang M.S., Ma B., Woods P.L., Cornelius P.L. GGE biplot vs. AMMI analysis of genotype - by-environment data. Crop Science. 2007. No 47. P. 643-655. DOI: 10.2135/cropsci2006.06.0374.

18. Solonechnyi P.N. AMMI and GGE biplot analyses of genotype-environment interaction in spring barley lines. Vavilov Journal of Genetics and Breeding. 2017. No 21(6). P. 657-662. DOI: $10.18699 / \mathrm{VJ} 17.283$.

19. Mohammadi R., Amri A. Genotype $\times$ environment interaction and genetic improvement for yield and yield stability of rainfed durum wheat in Iran. Euphytica. 2013. No 192(2). P. 227 249. DOI: 10.1007/s10681-012-0839-1.

20. Kadir M., Kaimuddin M., Forid B., Nusa Y. GGE-biplot analysis of yield stability in environment trial of tropical wheat (Triticum aestivum L.) genotype under dry season in Indonesia. Research on Crops. 2018. No 19(4) P. 680-688.

21. Aruna C., Rakshit S., Shrotria P.K., Pahuja S., Jain S.K., Siva Kumar S., Modi N.D., Deshmukh D.T., Kapoor R., Patil J.V. Assessing genotype-by-environment interactions and trait associations in forage sorghum using GGE biplot analysis. The Journal of Agricultural Science. 2015. No 1(1). P. 73-86. DOI: 10.1017/S0021859615000106.

22. Mare M., Manjeru P., Ncube B., Sisito G. GGE biplot analysis of genotypes by environment interaction on Sorghum bicolor L. (Moench) in Zimbabwe. African Journal of Plant Science. 2017. No 11(7). P. 308-319. DOI: 10.5897/AJPS2017.1538 
23. Seyoum A., Gebreyohannes A., Nega A., Nida H., Tadesse T., Tirfessa A., Bejiga T. Performance evaluation of Sorghum (Sorghum bicolor (L.) Moench) genotypes for grain yield and yield related traits in drought prone areas of Ethiopia. Advances in Crop Science and Technology. 2019. No 7(2). P. 423.

24. Qin J., Xu R., Li H., Yang C. Evaluation of productivity and stability of elite summer soybean cultivars in multi-environment trials. Euphytica. 2015. No 206(3). P. 759-773. DOI: 10.1007/s10681-015-1513-1.

25. Bhatiya A., Aditya J.P., Kumari V., Kishore N. GGE biplot \& ammi analysis of yield stability in multi-environment trial of soybean [Glycine $\max (\mathrm{L}$.$) Merrill] genotypes under rainfed$ condition of north western Himalayan hills. Indian Journal of Genetics and Plant Breeding. 2017. No 27(1). P. 227-238.

26. Mathobo R., Marais D. Evaluation of genotype $\mathrm{x}$ environment interaction using GGE-biplot on dry beans (Phaseolus vulgaris L.) in Limpopo province of South Africa. Australian Journal of Crop Science. 2017. No 11(05). P. 506-515. DOI: 10.21475/ajcs.17.11.05.p303.

27. Oliveira T.R.A., Gravina G.A., Oliveira G.H.F., Araújo K.C., Araújo L.C., Daher R.F., Vivas M., Gravina L.M., Cruz D.P. The GT biplot analysis of green bean traits. Ciencia Rural. 2018. No 48(6). DOI: 10.1590/0103-8478cr20170757.

28. Fan X.M., Kang M.S., Chen H., Zhang Y., Tan J., Xu C. Yield stability of maize hybrids evaluated in multi-environment trials in Yunnan, China. Agronomy Journal. 2007. No 99(1). P. 220-228. DOI: 10.2134/agroj2006.0144.

29. Solonechnyi P.M., Kozachenko M.R., Vasko N.I., Naumov O.G., Vazhenina O.E., Solonechna O.V., Dmitrenko P.P., Kovalenko A.I. GGE biplot analysis of genotype - environment interaction in spring barley varieties. Sel. Nasinn. 2014. Issue 106. P. 93-102. DOI: 10.30835/2413-7510.2014.42134.

30. Solonechnyi P., Vasko N., Naumov A., Solonechnaya O., Vazhenina O., Bondareva O., Logvinenko Y. GGE biplot analysis of genotype by environment interaction of spring barley varieties. Zemdirbyste-Agriculture. 2015. Issue 102. No 4. P. 431-436. DOI: 10.13080/za.2015.102.055.

\section{ЕКОЛОГІЧНЕ ВИПРОБУВАННЯ ГЕНОТИПІВ КВАСОЛІ В КОНТРАСТНОМУ СЕРЕДОВИЩІ}

Безугла О.М., Кобизєва Л.Н., Вус Н.О., Солонечний П.М.

Інститут рослинництва імені В.Я. Юр'єва НААН, Україна

Мета досліджень - визначити можливості окремо взятого генотипу та запропонувати селекціонерам вихідний матеріал, який адаптовано до регіону, де буде створено майбутній сорт.

Матеріали і методи. Для досягнення поставленої мети було проведено екологічне вивчення колекційних зразків квасолі (Phaseolus L.) в чотирьох пунктах, які відрізняються один від одного за кліматичними характеристиками: Інститут рослинництва ім. В.Я. Юр'єва НААН - м. Харків, східний Лісостеп; Устимівська дослідна станція рослинництва Інституту рослинництва ім. В.Я. Юр'єва НААН - Полтавська область, південний Лісостеп; Буковинська державна сільськогосподарська дослідна станція Інституту сільського господарства Карпатського регіону НААН - м. Чернівці, Полісся; Селекційногенетичний інститут - Національний центр насіннєзнавства та сортовивчення - м. Одеса, південний Степ.

Обговорення результатів. Оцінку генотипів та середовища досліджень проводили методом GGE biplot, який дозволяє візуально представити результати екологічного випробування. Установлено, що кліматичні умови південного Степу та Полісся України не дозволяють в повній мірі оцінити адаптивний потенціал генотипу через екстремальні для квасолі погодні умови в період її вегетації: Селекційно-генетичний інститут - Націона- 
льний центр насіннєзнавства та сортовивчення - високі літні температури та недостатнє вологозабезпечення рослин, Буковинська державна сільськогосподарська дослідна станція Інституту сільського господарства Карпатського регіону НААН - надлишок вологи. Але ці середовища необхідні для визначення стійкості до посухи і спеки (Селекційно-генетичний інститут - Національний центр насіннєзнавства та сортовивчення) та визначення генотипів 3 високою потенційною урожайністю (Буковинська державна сільськогосподарська дослідна станція Інституту сільського господарства Карпатського регіону НААН). Найбільш інформативні для оцінки адаптаційних властивостей генотипів $\epsilon$ погодні умови східного (Інститут рослинництва ім. В.Я. Юр'єва НААН) та південного (Устимівська дослідна станція рослинництва Інституту рослинництва ім. В.Я. Юр'єва НААН) Лісостепу України, які дозволяють оцінити генотип за стабільністю урожаю насіння.

Висновки. В результаті проведеного GGE biplot-аналізу, рекомендуємо при створення сортів для різних кліматичних зон України добирати батьківські форми, виходячи з погодних умов: південь України - посухостійкі генотипи з високою стійкістю до спеки (Holberg), Полісся - генотипи інтенсивного типу (Первомайська, Місцева бомба 5), Лісостеп - стабільні генотипи з високою посухостійкістю (Holberg, Надія, UD030104). Виявлені стабільні генотипи: Holberg, Отрада, UD0300104, Bogema, UD0300152, N 201-15 і Сінельниківська 8. 3 них поєднували стабільність та високу урожайність насіння: Holberg, Отрада, UD0300104 і Сінельниківська 8. Наближалися до «ідеального» генотипу Holberg i UD0300104.

Ключові слова: квасоля, генотип, середовище, GGE biplot

\section{ЭКОЛОГИЧЕСКОЕ ИСПЫТАНИЕ ГЕНОТИПОВ ФАСОЛИ В КОНТРАСТНЫХ СРЕДАХ}

Безуглая О.Н., Кобызева Л.Н., Вус Н.А., Солонечный П.Н.

Институт растениеводства шимени ВУ.Я. Юрьева НААН, Украина

Цель исследований - выявить возможности отдельно взятого генотипа и предложить селекционерам исходный материал, адаптированный к региону, где будет создаваться будущий сорт.

Материалы и методы. Для достижения поставленной цели, было проведено экологическое испытание коллекционных образцов фасоли (Phaseolus L.) в четырех пунктах, которые отличаются по климатическим характеристикам: Институт растениеводства им. В.Я. Юрьева НААН - г. Харьков, восточная Лесостепь; Устимовская опытная станция растениеводства Института растениеводства им. В.Я. Юрьева НААН - Полтавская область, южная Лесостепь; Буковинская государственная сельскохозяйственная опытная станция Института сельского хозяйства Карпатского региона НААН - г. Черновцы, Полесье; Селекционно-генетический институт - Национальный центр семеноведения и сортоизучения - г. Одесса, южная Степь.

Обсуждение результатов. Оценку генотипов и сред исследований проводили методом GGE biplot, который позволил графически визуализировать результаты экологического испытания. Рекомендуем при создании сортов для разных зон Украины подбирать родительские формы, исходя из погодных условий: юг Украины - засухоустойчивые генотипы с высокой жаростойкостью (Holberg), Полесье - генотипы интенсивного типа (Первомайська, Місцева бомба 5), Лесостепь - стабильные генотипы с высокой засухоустойчивостью (Holberg, Надія, UD030104).

Выводы. По результатам GGE biplot анализа были определены пункты экологического испытания, которые позволяют в полной мере оценить адаптивный потенциал генотипа: Институт растениеводства им. В.Я. Юрьева НААН и Устимовская опытная станция рас- 
тениеводства. В их условиях определены стабильные генотипы: Holberg, Отрада, UD0300104, Bogema, UD0300152, N 201-15 и Сінельниківська 8. Из них совмещали стабильность и высокую урожайность: Holberg, Отрада, UD0300104 и Сінельниківська 8. Приближались к «идеальному» генотипу Holberg и UD0300104.

Ключевые слова: фасоль, генотип, середа, GGE biplot

\section{ENVIRONMENTAL TRIALS OF A MODEL POPULATION OF PHASEOLUS VULGARIS L. IN CONTRAST CLIMATES}

Bezugla O.M., Kobyzeva L.N., Vus N.M., Solonechnyi P.M.

Plant Production Institute nd a V.Ya. Yuriev of NAAS, Ukraine

Purpose - assess the capacities of a particular genotype and to offer breeders starting material that is adapted to a region where a would-be variety will be created.

Materials and Methods. To accomplish this purpose, an environmental trial of collection bean (Phaseolus L.) accessions was carried out in four locations, which that differ in climatic characteristics: Plant Production Institute named after V.Ya. Yuriev NAAS - Kharkiv, eastern Forest-Steppe; Ustymivka Experimental Station of Plant Production of the Plant Production Institute named after V.Ya. Yuriev NAAS - Poltavska Oblast, southern Forest-Steppe; Bukovyna State Agricultural Experimental Station of the Institute of Agriculture of the Carpathian Region of NAAS - Chernivtsi, Woodlands; Plant Breeding and Genetics Institute -National Center of Seed and Cultivar Investigation - Odesa, southern Steppe.

Results and discussion. Genotypes and test environments were assessed by GGE biplot method, which made it possible to graphically visualize the environmental trial results. To create varieties for different zones of Ukraine, we recommend to select parents with due account for weather conditions: South of Ukraine - drought-resistant genotypes with high heat resistance (Holberg); Woodlands - intensive genotypes (Pervomaiska, Mistseva Bomba 5); ForestSteppe -stable genotypes with high drought resistance (Holberg, Nadiia, UD030104).

Conclusions. From the GGE biplot results, the environmental trial locations, which allow one to fully assess the adaptability of a genotype, were identified: Plant Production Institute named after V.Ya. Yuriev NAAS and Ustymivka Experimental Station of Plant Production. In their conditions, stable genotypes were distinguished: Holberg, Otrada, UD0300104, Bogema, UD0300152, N 201-15 and Sinelnikivska 8. Of these accessions, Holberg, Otrada, UD0300104 and Sinelnikivska 8 combined stability and high performance, approaching the "ideal" genotypes Holberg and UD0300104.

Key words: bean, genotype, environment, GGE biplot 